\title{
Reflection on the Nature of Copyright Law: Rectifying the Formalism of the Literary Copyright
}

\author{
Linxia Ke \\ law school \\ Huazhong University of Science \& Technology \\ Chongqing University of Posts and Telecommunications (CUPT) \\ Wuhan,China \\ klx327@126.com
}

\begin{abstract}
This article explored the problem of what the content of copyrighted was determined by. By tracing the history and nature of copyright law,we can see copyright law was born with the characteristic of formalism and broke away from the populace and the authors.This kind of copyright law deviates from the original intention of serving the public. As an external incentive system, if it can not adapt to the real demand of the domestic publishing industry and the authors, return to the civil position and drive force from the populace for their own development, ultimately it will be difficult to survive in the plump flesh and blood.
\end{abstract}

\section{Keywords-copyright;formalism; civil position}

\section{FOREWORD}

The chapter 8 , paragraph 8 of the Constitution of the United States authorizes to congress, "the protection of the exclusive rights of authors and inventors in their own writings and the discoveries can promote the progress of science and useful arts." The general provisions of China's "Copyright Law" writes, to protect the copyright of literary, artistic and scientific works or rights related to copyright, the law encourage the creation and dissemination beneficial to the socialist spiritual civilization and material creativity. Thus it is perhaps not an exaggeration to conclude that the purpose of copyright law is to promote the advancement of knowledge and education.

The developed countries continue to benefit from the copyright system is an indisputable fact. It is the main cause of

The western countries'implement of the TRIPS Agreement strongly in the worldwide .If the copyright is beneficial to the developing countries, the interests must be achieved by a hundred flowers blossom in the cultural patterns. Unfortunately, strong copyright law does not mean encouraging innovation, it also does not mean cultural prosperity.In the era of piracy's heyday, the national book publication total still rises year by year. In the republican era ,the copyright is less developed, such as copyright protection, It also failed to stop the well-known writer to be born, such as Yu Dafu, Guo MoRuo, Lin Yutang. Lu Xun can abandon all business, focus on in the creation and become an giant literary who was out-and-out "selling text as a living".For literary copyright, it is probably not so simple to strengthen the protection of copyright to encourage creativity.

\section{THE FORMALISM OF THE COPYRIGHT LAW}

\section{A. The Defect on the Birth.}

In the book of "The Evolution of Modern Intellectual Property Law", it has mentioned that modern intellectual property law highlights two characteristics.The first feature is the emergence of modern intellectual property registration system, the second is intellectual property law has its own attention to the aesthetic form . To reflect on the history of the development of china's intellectual property law, the establishment of the intellectual property system is a mandatory institutional change under the leadership of the government. In urgent political reality of accession to the World Trade Organization, China establish high standards meeting with international standards of intellectual property law within a very short time. At the same time, the legislature almost ignored such objective facts as the awareness of domestic property right and the low level of knowledge production and use usefulness, Its concern is the structure of the shape of the law,It can not take into account the fate of intellectual property law in the future.Its attention on form is a prominent feature of the intellectual property legislation. In this top-down legislative changes, external pressure is an important factor, internal factors are artificially ignored.Domestic market of the publishing industry, the relationships on publisher and the original author, especially the aspirations of the creative people are simply suppressed.

As can be seen, the formalism,focusing on the form rather than the content, is an inherent feature of china's copyright law, One-sided pursuit of the external form of copyright law while ignoring the content is flawed,the copyright law in 1991 began

to look for opportunities to make up for the defect from the date of birth.

\section{B. disjointedness at the Institutional and Practical Level.}

In general, what the legislators consider is the normative guidelines to the community of the copyright owners, Stimulating innovationand ensuring full access to knowledge products.More specifically, the cost of copyright products, rational use and appropriate statutory license is a considered 
part of the legislators, especially in some countries with insufficient manufacturing capacity of their own literature.

For a single creator, the impact of copyright law is uncertain, It is difficult to estimate the role of copyright law playing in the process of a person to become a creative person. What are the factors that affecting the creation process is an unavoidable problem. First, creative work is a complex process, both men and women, regardless of age, regardless of time, regardless of the occasion, regardless of quality, anyone can own the copyright of a text.The first concern of the creators is whether superior or inferior the text is , the ability to get the reader's identity or the channels of publication and communication. Where there is no communication.where there is no copyright, copyright is the secondary consideration. Secondly, in a deeper level, the creative process can not be separated from civil life.Creation based on copyright can not ignore the reality or deviate from the civil position.civil language and civilians perspective should be characteristics of literary copyright.Literary copyright comes from the folk, public service is a consensus can be reached.

As a guide,copyright law should be based on the needs of the creative people.The improvement of the copyright law should be under a down-top improvement,not a top-down one . In fact, the copyright is mostly looked as economic or commercial rights, the interests of publishers dominate the development of copyright law, but no one wants to listen to the views of the creators. The foundation of the literary copyright lies in the ethnic group and civil, If we are not concerned on the individual creator, not concerned about the creative Process and the spreading channels, such kind of copyright law is only a building on unrealistic technology.In short, copyright system is not well served for the practice.

\section{WHY COPYRIGHT LAW IS INEFFICIENT}

\section{A. The Market Structure of Copyright Industry Limits the Efficacy of Copyright Law}

Copyright law which is lack of respect for the rules of the publishing industry is difficult to obtain self-conscious compliance and implementation.It is a fact that in many cases,the copyright belongs to the authorized organization ,not the original author.the copyright is usually awarded to an organization, such as the publishers.In the business structure of original author - publisher , these forprofit organizations start to clamor that the protection of intellectual property is good for business and the interests of the majority of the public, the catalyst of national innovation and technological progress. They are lobbying the authorities while seeking opportunities to participate in the legislative and the formulation of the rule of law.In fact, copyright law is not so much related to the interests of the author as it relates to the copyright holder is authorized.Calculating the income of the copyright of the works of $\mathrm{Lu}$ Xun, the publisher had received a huge amount of interest, but the real original author or the author's heirs have gained little,So, It is clear who are the people benefit form copyright expansion.Obviously,compared to the publishers, the incentive of copyright is weak for the author.The incentive of copyright law for the creation is usually indirectly passed to the author through the publishers. the passing ,indirect, tortuous incentive to the original creation can not produce much effect.

\section{B. Can Strengthening Copyright Protection Encourage Innovation?}

In accordance with the original intent of copyright, copyright protection will encourage investment in innovation, excitation of passion for innovation which are beneficial to the prosperity of the social and cultural career.The fact is in many areas, intellectual property is not the determinant of innovation .Especially for literary copyright, the copyright system is unlikely to be the determining factor to stimulate the natural creative passion or as a creative force and source.

Without the copyright's incentives, will personal creation not happen?As the British Commission on Intellectual Property Rights had mentioned, stronger copyright protection may help to stimulate the development of local cultural industries in developing countries, but it may be necessary for the development of these industries, but not sufficient conditions. The literary Copyright is closely contact with the cultural characteristics of a country. The creation is mostly a natural process. Nobel Prize winner Mo Yan admitted that childhood experience inspires his creativity; Yasunari Kawabata also said orphan's sadness was the undercurrent of the debut even all works, his inspiration came from the life of grief and loneliness.In the era of everyone can become the owner of literary copyright, the copyright system is difficult to promote innovation for fragmented individual creators. An important example is the network literature, copyright work in this area is often seen as the enjoyment of spirit rather than working as business assets linked to copyright.its creation is not related to the keeping or abolishing, width and striction of copyright law.

For every potential creator, stronger copyright protection does not always mean encouraging, especially for the first .The degree of protection of copyright and creative quantity or quality does not necessarily positively correlated.For a single author, the creative process may be accumulated year by year in the previous works on the basis of an independent process. The fortuity and discontinuity of this process is clearly different from the team-creation.

According to a recent research report ,formal intellectual property system is only applicable to a small proportion of commercial activities (such as a large manufacturing company) .but for other small companies, other non-formal protection methods and technical means of information is usually more efficient.Similarly,For individual creative people scattered in the civil, the copyright laws does not produce a strong stimulation.

\section{WHAT KIND OF COPYRIGHT LAW WE NEED}

We should reflect, what kind of copyright law we want in the end?Surely, we need the copyright law can promote knowledge and education progress .For the copyright law, the best state is to promote cultural prosperity in the maintenance of the author's interest, the lowest limit is to 
ensure the public unhinderedly to get literary works which are in the period of copyright protection.If the high-quality copyright laws is unattainable, the requirement is a minimum.

\section{A. The Opening of the Free Service System.}

High standards of copyright law on knowledge products have a significant impact in the communication in the developing countries.The difficulty of public access to knowledge products will increase, even more unfavorable for the poor.However, literature involving ideology has the properties of public goods, the government has the obligation to provide resources.

Based on the obligation,in the existing copyright system, the national copyright administration department can preside to establish a separate copyright trading platform. Developing the copyright procurement policy through this platform, the government can get below-market or free copyright, low-cost or open work will have priority.For example, in 2005, 21 world-renowned writer donated novels' copyrights which is compiled and published as "About love" ,about all of the copyright in the novel by the writer are granted free of charge.In 2008, the copyright owners $\mathrm{Ou}$ Laigang voluntarily donated the copyrighted work "Dragon" pattern and hope that the copyright are used for the public, and we encourage more copyright owners take such a meaningful action.A method can be tried: copyright management department consulting with the copyright owners gets part of the copyright work to create a digital library of copyright works providing online free services, these free services can be extended to academic journals from literary works.

\section{B. The Expanding Disclaimer of "Fair Use".}

In the era of knowledge economy, our long-term focus on copyright, not only because of the creative people, but also because the copyright protection of books and learning materials make it difficult for countries to achieve the goals of education and research.

Wanting to break through the copyright restrictions and obtaining the copyright works often is the unattainable desire, the rational use of the system and statutory licensing system recurrently lapse.the internet industry sets encryption and anti-decryption measures together with the copyright rules, these technical barriers are more stringent restrictions than copyright law.

Rational use of the expansion of the system is becoming an urgent need.we should ensure that the internet users have the lawful right to use,such as learning, research and for educational purposes printing and distributing network information and coping of excerpts of notes and comments, browse abstracts, etc...For the circumvention of technical protection measures such as encryption, we do not yet have the conditions to follow the United States' Digital Millennium Copyright Act.It is time to decisively identify these technology encryption illegal and to ensure the right of proper use.

\section{V.CONCLUSION}

In order to eliminate the ideal views of most people on today's copyright law.It has the characteristic of formalism.This article once again stressed that,the copyright owner is not equal to the creative people, dissemination and creation of works are two kinds of different processes,Strengthening copyright protection does not mean the incentive to creation. The role of copyright law in the development of literary copyright is artificially exaggerated the extent to literary innovation depends on many different factors, especially culture, public information policies and the environment,Such as the degree of freedom of speech development and management.Zhang Letian puts forward the view in the book of "bid farewell to ideal people's commune system research", that is the big commune system make the rural economy tends to collapse. This crisis makes the authority make concessions to select the people's commune system and establish the mode of the production team as the basic solution accounting unit .It is free to organize production and distribution group.He uses the "“external shocks-village traditional interaction" mode to describe as follows:if the external coercion can not adapt themselves to the village tradition, then, it is likely to be weaken by the powerful traditional power or disappear.Similarly, as the external institutional incentives, , if copyright law can not conform to the real demands of domestic publishing industry and the authors, returning to civil position and driving force from it for their own development, ultimately it is difficult to survive in the plump flesh and blood.it is one of the reasons that the copyright law is modified several times in recent years but difficult to get its wish.

\section{REFERENCES}

[1] National Overview of the total book publishing: 2011, the national publication of books, journals, newspapers, total print runs of 309923 000000 sheets, equivalent to 7.1701 million tons of paper consumption,paper consumption increased to $5.58 \%$ compared with the previous year. http://www.sina.com.cn, 2012.8.6,China Press reported

[2] Lu Xun Rights on the Activities of Shanghai Dynasty(1927-1936) .

[3] The formalism is fragmented form content of the organic links, onesided pursuit of form and ignore the contents of a metaphysical viewpoint and method. "Formalism" comes from the Greek, meaning a mere formality.

[4] UK Commission on Intellectual Property Rights(CIPR),"Integrating Intellectual Property Rights and Development Policy"Report Summary,2004,pp.8.

[5] UK Commission on Intellectual Property Rights(CIPR),"Intellectual Property Rights and Development Policy"Report Summary, 1999,pp.14.

[6] UK Commission on Intellectual Property Rights(CIPR),"Integrating Intellectual Property Rights and Development Policy"Report Summary,2004,pp.4.

[7] The 21 World writer donated Copyright published in book"tells of love",http://www.china.com.cn/chinese/RS/1048544.htm, December 2, 2005,Beijing News.

[8] Ou Laigang donate the "Dragon" pattern Copyright,http://news.qq.com/a/20080426/001738.htm, April 26 ,2008, Inner Mongolia News Network. 
[9] UK Commission on Intellectual Property Rights(CIPR),"Integrating Intellectual Property Rights and Development Policy"Report Summary,2004,pp.14.
[10] Feng zhiyu,Olson "Logic of Collective Action "Reading Notes,http://www.douban.com/note/57613267/,January 21, 2010. 